(C) <2019>. This manuscript version is made available under the CC-BY-NC-ND 4.0 license http://creativecommons.org/licenses/by-nc-nd/4.0/

The definitive publisher version is available online at 10.1016/j.atmosenv.2018.12.015 


\title{
Investigation of mercury emissions from burning of Australian eucalypt forest surface fuels using a combustion wind tunnel and field observations
}

\author{
Dean Howard ${ }^{1,2}$, Katrina Macsween ${ }^{1}$, Grant C. Edwards ${ }^{1}$, Maximilien \\ Desservettaz $^{3}$, Elise-Andrée Guérette ${ }^{3}$, Clare Paton-Walsh ${ }^{3}$, Nicholas C. \\ Surawski $^{4,5}$, Andrew L. Sullivan ${ }^{5}$, Christopher Weston $^{6}$, Liubov Volkova ${ }^{6}$, \\ Jennifer Powell ${ }^{7}$, Melita D. Keywood ${ }^{7}$, Fabienne Reisen ${ }^{7}$, C. P. (Mick) Meyer ${ }^{7}$ \\ ${ }^{1}$ Department of Environmental Sciences, Macquarie University, North Ryde, NSW, \\ Australia \\ ${ }^{2}$ Environmental, Earth and Atmospheric Sciences, University of Massachusetts Lowell, \\ Lowell, MA, USA \\ 3 Centre for Atmospheric Chemistry, University of Wollongong, Wollongong, NSW, \\ Australia \\ 4 School of Civil and Environmental Engineering, University of Technology Sydney, Ultimo, \\ NSW, Australia \\ ${ }^{5}$ CSIRO Land and Water, Canberra, ACT, Australia \\ 6 School of Ecosystem and Forest Sciences, The University of Melbourne, Creswick, VIC, \\ Australia \\ 7 CSIRO Oceans and Atmosphere, Aspendale, VIC, Australia
}

\begin{abstract}
Environmental cycling of the toxic metal mercury is ubiquitous, and still not completely understood. Volatilisation and emission of mercury from vegetation, litter and soil during burning represents a significant return pathway for previously-deposited atmospheric mercury. Rates of such emission vary widely across ecosystems as they are dependent on species-specific uptake of atmospheric mercury as well as fire return frequencies. Wildfire burning in Australia is currently thought to contribute between 1 and $5 \%$ of the global total of mercury emissions, yet no modelling efforts to date have utilised local measurements of fuel mercury concentrations or local mercury emission factors/ratios. Here we present laboratory and field investigations into mercury emission from burning of surface fuels in dry sclerophyll forests, native to the temperate southeastern region of Australia. From laboratory data we found that fire behaviour — in particular combustion phase — has a large influence on mercury emission
\end{abstract}


and hence emission ratios. Further, emission of mercury was predominantly in gaseous form with particulate-bound mercury representing $<1 \%$ of total mercury emission. Importantly, fuel mercury concentrations, mercury emission factors, and mercury emission ratios from both laboratory and field data all show that gaseous mercury emission from biomass burning in Australian dry sclerophyll forests is currently overestimated by around $60 \%$.

Keywords: gaseous elemental mercury, biogeochemical cycling, emissions, biomass burning, Australia

\section{Introduction}

The global nature of mercury $(\mathrm{Hg})$ pollution has long been recognised [20]. With natural sinks, sources and cycles, the unique physicochemical properties of this toxic metal allow for constant transfer between biological, terrestrial, 5 aquatic and atmospheric reservoirs, making it ubiquitous throughout the environment [24, 63, 48, 44. Increases in mercury emission sources due to human activities have perturbed this natural cycle in a manner that has become a threat to human and ecosystem health [71, 72, 4]. This threat is globally recognised in the Minamata Convention on Mercury [43, aimed at reducing anthropogenic emissions of mercury to the environment. Article 19 of the convention addresses the need to understand mercury's complex natural cycling by calling for parties to the convention to, where possible, increase research and extend current monitoring efforts.

In the atmosphere, mercury exists largely in the form of gaseous elemental mercury (GEM), with the operationally-defined gaseous oxidised mercury (GOM) and particulate bound mercury (PBM) forms generally thought to comprise less than $10 \%$ of total atmospheric mercury [60]. The long atmospheric lifetime of GEM [estimated at between 5 and 12 months 46, 37, 38] means transport of mercury can take place through the atmosphere - but also in watercourses and the ocean - to regions far-removed from their sources. From the atmosphere, mercury is deposited to terrestrial surfaces and waterways, 
taken up by vegetation, and re-emitted in a complex natural cycle that is still not completely understood [68, 4, 3]. Atmospheric mercury may be taken into vegetation during photosynthesis [62] or deposited via dry or wet deposition processes onto vegetated surfaces, whereby it can be incorporated into the cell membrane through foliar uptake [49, 69, 36]. Throughfall, litterfall and surface dry/wet deposition processes deliver atmospheric mercury to the underlying surface litter, whereby leaf decomposition and further atmospheric deposition enhance soil mercury levels due to binding of mercury to organic matter within the soil [82, 34. Vegetation type, coverage and growth rates, and atmospheric mercury concentrations all affect the rate at which mercury is stored within these components 41, 22, 14.

Biomass burning releases mercury from these stores back into the atmosphere through volatilisation of mercury within biomass during combustion and 35 through thermal desorption of mercury bound within the soil matrix [51]. Herein we limit the definition of biomass burning to free-burning vegetation fires (both intentionally and accidentally ignited) and exclude burning of biomass for industrial/cultural purposes (e.g. wood burners and stoves). The release of mercury from biomass burning is an important yet complex and poorly understood com40 ponent of the global mercury cycle as it can lead to redistribution of mercury to sensitive ecosystems where methylation may occur, or it can result in direct human exposure to mercury through inhalation of biomass burning plumes [65]. Mercury is often completely volatilised from combusted biomass [27] and this emitted mercury is largely in the form of GEM [26, 27, however Obrist et al.

45 [56] showed that increasing PBM levels are associated with increasing fuel moisture and decreasing fire intensity. The lower atmospheric lifetime of PBM leads to changing mercury deposition patterns in response to emission partitioning [66]. The extent to which thermal desorption takes place in the soil is related to the intensity of the fire, as low intensity, slow-moving fires may heat the soil 50 to higher temperatures than faster moving, higher-intensity fires 80. As such, release of mercury is not only dependent on the loading of mercury within the fuels but also on fire behaviour. 
Ecosystem-scale estimates of mercury release from biomass burning are typically achieved by applying a mixture of empirical and remotely-sensed data. Burned areas are often derived from satellite data products, from which emission of mercury (or other chemical species) can be estimated by applying an empirically-derived emission factor, or an emission ratio with reference to another chemical species along with its emission factor. These approaches are outlined generally below [1]:

$$
\begin{gathered}
E_{x}=A \cdot L \cdot B E \cdot E F_{x} \\
E_{x}=A \cdot L \cdot B E \cdot E F_{y} \cdot E R_{x / y}
\end{gathered}
$$
where $E_{x}$ is the emitted mass of species $x, A$ the area burned, $L$ the fuel loading in mass per area, $B E$ the burning efficiency and $E F_{x}$ the emission factor for species $x$. Where emission factors for species $x$ are poorly constrained or not known, these can be determined by using an emission ratio $E R_{x / y}$ and applying this to the known emission factor for species $y$. Emission ratios for mercury are generally derived from ground- or aerial-based measurements of smoke plumes and are typically reported with respect to carbon monoxide $(\mathrm{CO})$, although ratios with carbon dioxide $\left(\mathrm{CO}_{2}\right)$ have been presented by Brunke et al. [10]. The use of emission ratios is advantageous as, due to turbulent mixing in the plume, it provides an average enhancement across the horizontal and vertical extent of the fire. Emission factors are instead based on fuel mercury concentrations and empirically-derived estimates of release during combustion. These provide the most direct estimate of mercury release from specific vegetation types and from soils when the amount of biomass burned is known, yet require significant sampling to obtain data suitable at an ecosystem scale [5].

Australia is a particularly fire-prone continent, and global-scale models of mercury emission from biomass burning estimate that emissions over Australia represent between 1 and $5 \%$ of the global total [25, 65. Based on the National Oceanic and Atmospheric Administration's Advanced Very High Resolution Ra- 
diometer (NOAA-AVHHR) satellite data, an average of 41 million ha (5 \% total land mass) burned annually in the years 1997-2011 [Fig. 1, 47]. Home to 32 major vegetation groups [6] and spanning a broad range of climates, Australia's ecosystems are subject to varying degrees of fire frequency and intensity. Tropical savannah in northern Australia may undergo burning every 1-2 years [52], whilst temperate forests in south-eastern Australia typically experience burna longer growing period. Simplification of vegetation types across continental scales is necessary in modelling biomass burning mercury emissions, a global example of which is the terrestrial ecoregion [57, 7, see Fig. 1]. To date, the most extensive investigation into vegetation mercury content across Australia 90 was performed by Packham et al. [58] (see Table 1), yet these have not been used in any subsequent mercury modelling efforts. Modelling estimates of mercury emissions from biomass burning in Australia have instead so far only been obtained using empirically-derived emission factors or emission ratios from studies undertaken in the Northern Hemisphere [27, 25. The resulting estimates of annual release over Australia are currently poorly constrained, spanning a range between $7 \mathrm{Mg} \mathrm{Hg} \mathrm{a}^{-1}$ and $129 \mathrm{Mg} \mathrm{Hg} \mathrm{a}^{-1}$ 25, 55, 58, 15, 54, 65.

In response to the general lack of knowledge surrounding mercury in Australian vegetation - and the complete lack of Australian-derived emission ratios or emission factors in Australian mercury emission modelling - this paper reports on and compares two different studies of mercury release from the burning of Australian native forest surface fuels. In this paper we limit our analysis to the eucalypt-dominated dry sclerophyll forests, the most widespread forest type in south-eastern Australia [53. Native to Australia, eucalypts have been cultivated globally and can now be found on all inhabited continents. Experimental burns of dry sclerophyll surface fuels took place in a combustion wind tunnel designed for the study of combustion of vegetation fuels [73, which provided the unique advantage that the influence of fire propagation on emissions could be investigated. Results from this laboratory-scale study are then compared with observations of biomass burning plumes from the Cape Grim Baseline Air Pollu- 

mine experimental fuel moisture content (MC). Subsamples were oven-dried at $105^{\circ} \mathrm{C}$ for 24 hours and then reweighed, from which fuel moisture content was calculated [50]. For further detail regarding fuel collection see Sullivan et al. 74]. These were dried and homogenised, then mercury contents were analysed using a Milestone direct mercury analyser (DMA-80) and US EPA method 7473. The 
sampling protocol involved triplicate sampling to determine precision, the introduction of blanks to reduce memory effects and liquid standards to determine analytical accuracy. Calibrations were checked using National Institute of Standards and Technology (NIST) traceable Standard Reference Material (SRM, NIST 1575a and 2709a).

\subsection{Experimental burns}

Experimental burns were performed at the CSIRO Pyrotron facility, a $25.6 \mathrm{~m}$ long stainless-steel wind tunnel with a $2.0 \times 2.0 \mathrm{~m}$ cross-sectional area and a $2.0 \times 4.8 \mathrm{~m}$ working section designed for investigations into fire behaviour and emissions. Within the working section, fuel beds up to $1.5 \times 4.8 \mathrm{~m}$ can be prepared and combusted [for details see 73, 75, 74]. An array of 62 thermocouples within the working section record gas temperatures 1-3 cm above the fuel during the experimental burns. Wind speed within the tunnel was set at $1.0 \mathrm{~m} \mathrm{~s}^{-1}$ for all experimental burns. Prior to each experimental burn, fine fuel moisture contents were measured using an A\&D MF-50 moisture meter [12] and a mass equivalent to a dry fine fuel weight of $1.00 \pm 0.02 \mathrm{~kg} \mathrm{~m}^{-2}$ was gathered and spread evenly across the working section. Four treatments were applied in this experiment, each with a different load of coarse fuels. These required the addition of $0.0 \mathrm{~kg} \mathrm{~m}^{-2}$ (i.e. control), $0.2 \mathrm{~kg} \mathrm{~m}^{-2}, 0.6 \mathrm{~kg} \mathrm{~m}^{-2}$ and $1.2 \mathrm{~kg} \mathrm{~m}^{-2}$ coarse fuels to the $1.0 \mathrm{~kg} \mathrm{~m}^{-2}$ fine fuels. Coarse fuel loads were split evenly between the two size fractions $(6-25 \mathrm{~mm}$ and $25-50 \mathrm{~mm}$ ) and distributed evenly across the working section.

The fuel bed was ignited against one edge of the working section using a $1.5 \mathrm{~m}$ channel filled with ethanol that was lit with a butane lighter. In addition to investigating changes in coarse fuel load, differing fire behaviour was also investigated by lighting the fuel such that the fire propagated with the wind (heading) or against it (backing). Fuel bed sizes for heading fires were $6.0 \mathrm{~m}^{2}$ $(1.5 \times 4.0 \mathrm{~m})$. Due to the slower propagation of backing fires, fuel bed sizes were set at $3.0 \mathrm{~m}^{2}(1.5 \times 2.0 \mathrm{~m})$. In total, 22 experimental burns took place during the experiment. Working section blanks were determined by igniting 
ethanol spread across the working section, with no appreciable enhancement of the same 2537A used for continuous sampling. $\mathrm{CO}_{2}$ and $\mathrm{CO}$ concentrations were quantified using a Fourier Transform Infrared Spectrometer coupled to a 
multi-pass optical cell (White cell FTIR). Mole fractions were retrieved from tively describe the relative influence of flaming and smouldering combustion on atmospheric emissions [16. The Byram fire line intensity was calculated for each burn by multiplying the lower heating value of the fuel by the fuel consumed 
and the rate of spread [11.

$$
\begin{gathered}
E F_{y}=F C \cdot F V \cdot 1000 \cdot \frac{M W_{y}}{12} \cdot C_{y} \\
E F_{T H g / F u e l}=\sum_{f}\left[T H g_{f}\right] \cdot F_{f}-\frac{\sum_{r}\left[T H g_{r}\right] \cdot L_{r}}{L} \\
M C E=\frac{\Delta C O_{2}}{\Delta C O_{2}+\Delta C O}
\end{gathered}
$$

Here $F C$ is the fractional carbon content of the fuel, $F V$ is the fraction of fuel carbon volatilised, $M W_{y}$ is the molecular weight of species $y=\mathrm{CO}_{2} / \mathrm{CO}, C_{y}$ is the percentage of observed emitted carbon species that were in the form species $y,[\mathrm{THg}]_{f, r}$ is the total mercury content of each fuel type $f=$ leaves/bark/twigs/coarse 235 material or $r=$ fine/coarse combustion residue and $F_{f}$ is the fractional mass of fuel type $f$.

\subsection{Biomass burning plumes at CGBAPS}

In January and February of 2016, the north-west of Tasmania experienced extensive bushfire burning, with over 140 fires covering $>97,000$ ha reported [30, 2. Throughout this period CGBAPS, located on the north-west cape of Tasmania's main island, was intermittently exposed to air masses affected by these fires. Instrumental setups at CGBAPS have been described in detail earlier [67, 45]; briefly GEM was sampled at this site from a $10 \mathrm{~m}$ mast using a Tekran $2537 \mathrm{~B}$ and $\mathrm{CO} / \mathrm{CO}_{2}$ were sampled from a $70 \mathrm{~m}$ mast and quantified using a Picarrro G2301.

Figure $2 \mathrm{a}$ shows the time series of these three species during this period. Concentrations for all species were resampled to match the lowest frequency data $\left(1\right.$ hour $\left.^{-1}\right)$. Identification of biomass burning plume strike events was achieved using the selection process described by Desservettaz et al. [16, whereby burning events underwent a first round of selection by identifying enhancements in CO. A second round of selection was employed, ensuring concomitant enhancement of both $\mathrm{CO}_{2}$ and GEM. The third round of selection described by Desservettaz 
et al. [16] (identification of mixed plumes) was not employed. As such, these events may be indicative of emissions from multiple fires. Background concentrations of the three species were calculated as the average taken 2 hours before and after the identified event. Emission ratios and MCE were then calculated in the same manner as for the experimental burns.

Air mass back trajectories were computed for plume strike periods using the NOAA Hybrid Single Particle Lagrangian Integrated Trajectory (HYSPLIT) Model [17, 18, 19, 70]. Actively burning regions on corresponding days were identified using National Aeronautics and Space Administration (NASA) Moderate Resolution Imaging Spectroradiometer (MODIS) hotspot data. Figure 2p shows trajectory and hot spot data, along with selected vegetation community data [6]. Two vegetation and soil sampling sites within a Eucalyptus obliqua rainforest were selected based on these data and accessibility (Site 2, Fig. 1 ] and Fig. 2b). These sites were both within $\sim 300 \mathrm{~m}$ proximity to a road that served as a fire break during the burning event, with vegetation on one side visibly burned whilst the other side remained intact. Fine surface fuels (fallen leaves, twigs, bark) as well as soils at depths of $0-2$ and 5-10 cm were collected. Sample collection took place in May 2017 using trace metal sampling techniques and samples were analysed for total mercury content using the technique described in Section 2.1.

\section{Results}

\subsection{Total mercury in fuels and mercury emission factors}

Total mercury concentrations measured in Site 1 fine fuels ranged from $0.38 \mu \mathrm{g} \mathrm{kg}^{-1}$ to $100.14 \mu \mathrm{g} \mathrm{kg}^{-1}$. Split according to fuel type (Table 2), leaves contained the highest concentrations, followed by bark and twigs. Relative mass loading for fine materials was $40.5 \%$ (leaves), $7.3 \%$ (bark) and $51.7 \%$ (twigs), resulting in mean total mercury loads of $32.5 \mu \mathrm{g}, 2.0 \mu \mathrm{g}$ and $6.0 \mu \mathrm{g}$ respectively, per kilogram of total fine fuel. Total mercury loads from coarse fuels were significantly smaller and ranged from $0.8 \mu \mathrm{g} \mathrm{kg}^{-1}$ to $5.0 \mu \mathrm{g} \mathrm{kg}^{-1}$. 
Total mercury concentrations in leaves from Site 2 were lower than from Site 1, whilst bark and twigs showed comparable concentrations. Soil total mercury concentrations showed relatively large variability between the unburned and burned sites (mean values at $0-2 \mathrm{~cm}$ were $29.4 \mu \mathrm{g} \mathrm{kg}^{-1}$ and $49.3 \mu \mathrm{g} \mathrm{kg}^{-1}$ respectively). Relative concentrations between the upper and lower soils sampled were similar for both sites $\left(\sim 5 \mu \mathrm{g} \mathrm{kg} \mathrm{kg}^{-1}\right.$ higher for soils $0-2 \mathrm{~cm}$ from the surface than $5-10 \mathrm{~cm})$.

Mean mercury loss from combustion was considerable, with $95 \%$ and $97 \%$ of mercury lost from fine and coarse fuels, respectively. There was a very minor difference in mean total mercury loss between heading and backing flaming modes for fine fuels (96\% loss for heading and $92 \%$ for backing), though no such difference was observed for coarse fuels. Due to the low mercury concentrations in coarse fuels, emission factors based on fuel mass balance $\left(E F_{T H g / f u e l}\right)$ effectively decreased with increasing coarse fuel loads. These values were 28.7 $\pm 8.1 \mu \mathrm{g} \mathrm{kg}^{-1}, 24.9 \pm 7.4 \mu \mathrm{g} \mathrm{kg}^{-1}, 20.0 \pm 6.6 \mu \mathrm{g} \mathrm{kg}^{-1}$ and $15.9 \pm 5.9 \mu \mathrm{g} \mathrm{kg}^{-1}$ for fuel loads with $0.0 \mathrm{~kg} \mathrm{~m}^{-2}, 0.2 \mathrm{~kg} \mathrm{~m}^{-2}, 0.6 \mathrm{~kg} \mathrm{~m}^{-2}$ and $1.2 \mathrm{~kg} \mathrm{~m}^{-2}$ coarse fuels, respectively.

\subsection{Overview of experimental burns}

An overview of the fire behaviour measurements is presented in Table 3 . Moisture contents at the beginning of each burn ranged between 10.0 and $12.7 \%$. Maximum temperatures (given for each thermocouple in the working section, not aggregated across burns as a whole) were generally higher for heading fires than for backing, though were not statistically different. End of forward spread (EOFS) was defined as the point in time when the apex of the head fire reached the end of the fuel bed and was used to determine the rate of spread (equal to the length of the fuel bed divided by EOFS). Due to the parabolic head fire shape [13], areas of unburned material along the flanks of the fire remained at EOFS. Heading fires progressed along the fuel bed at a much faster $(\sim 9$ times) rate than backing fires, consequently showing considerably higher Byram fire line intensities. Based on the Byram fireline intensities, these burns are 
best described as low-moderate intensity, typical for prescribed burning [76]. Flaming combustion durations for heading fires increased slightly with higher coarse loading (Fig. 3), partly due to longer flaming periods of coarse fuels and partly due to a slowed rate of spread. Three distinct periods of the experimental burns were defined: flaming progression (FP) from ignition to EOFS, flaming stationary (FS) from EOFS to the cessation of all flaming combustion (note that "stationary" here refers to the apex of the fire and not the still-progressing flanks) and smouldering (SM) from the end of flaming combustion until the end of the experimental burn.

Carbon release during combustion from all experimental burns was largely in the form of $\mathrm{CO}_{2}$ and $\mathrm{CO}$, with $\mathrm{CO}_{2}$ representing the majority of this release (92 to $97 \%$ C) and CO representing 3 to $7 \%$. Figure 3 shows that, for heading fires, peak $\mathrm{CO}_{2}$ occurred before peak $\mathrm{CO}$. The timing of these peaks did not consistently coincide with either EOFS or flame duration, however the period between the peaks did increase with increasing coarse fuel loads. Patterns for $\mathrm{CO}_{2}$ and $\mathrm{CO}$ concentrations during backing fires showed an initial peak following ignition preceding a steady decline for the duration of the burn. Distinct ranges of MCE were observed by the open-path instrument during each combustion stage, with FP showing an MCE range of 0.96 to 1, FS a range of 0.88 to 0.96 and SM a range of 0.80 to 0.88 .

Figure 3 shows that release of GEM during heading fires occurred predominantly during the flaming progression stage, with a peak in GEM observed prior to EOFS and very low concentrations following the end of all flaming combustion. The timing in peak GEM was earlier for bag data than for continuous data - this was attributed to the long sampling period of the 2537A (2.5 min) relative to the changes in GEM release from flaming combustion. Bag sampling frequency was kept at $1 \mathrm{~min}^{-1}$ during flaming combustion and so finer detail during this stage could be resolved. GEM enhancements during backing fires exhibited a minor peak during the first 5-10 minutes of combustion and a slow, continual decrease during the extended flaming combustion phase. This pattern did not change considerably across coarse fuel loads and so data for all backing 
fires are shown here as an aggregate. GEM represented the majority of liberated mercury for all experimental burns, with PBM accounting for $<1 \%$ of mercury emission. Emission of PBM showed no relationship with fire spread or fuel loading.

\subsection{GEM emission ratios}

For experimental burns the mean GEM emission ratio with respect to $\mathrm{CO}_{2}$ $\left(E R_{G E M / C O 2}\right)$ was $5.95 \pm 0.02 \times 10^{-9}$ and with respect to $\mathrm{CO}\left(E R_{G E M / C O}\right)$ 350 was $0.82 \pm 0.01 \times 10^{-7}$ (Table 4 ). Emission ratios obtained with both bag and continuous sampling methods showed good agreement and are reported here as an aggregate total. Distinct differences in both $E R_{G E M / C O 2}$ and $E R_{G E M / C O}$ were observed for each of the experimental burn stages with larger values observed during the initial stages of the burns (Table 4. Fig. 4a,b). This is consistent with the GEM enhancement time series showing that most GEM was released during the flaming progression stage of the experimental burns.

No such distinction between combustion stages was able to be resolved in the CGBAPS plume strike data, with GEM enhancements showing more linear relationships with both $\mathrm{CO}_{2}$ and $\mathrm{CO}$ enhancements across all plume events

(Fig. 44,d). $E R_{G E M / C O 2}$ from the CGBAPS plume strike data was significantly higher than that observed during the experimental burns $\left(9.77 \pm 0.08 \times 10^{-9}\right)$. The value for $E R_{G E M / C O}$ from CGBAPS, at $0.58 \pm 0.01 \times 10^{-7}$, was slightly lower than that from all experimental burn data but comparable with that calculated from flaming stationary observations. We note that only data from 365 plume strike events 1 and 5 can reasonably be believed to have originated from eucalpyt forest biomass burning (see Fig. 2b). Removing data from events $2-4$ (likely from heathland and grassland burning) did not significantly alter the resulting ER values.

Mercury emission factors based on emission ratios were calculated from the experimental burn data only and showed similarly large variability with burn stage, with values for both $E F_{G E M / C O 2}$ and $E F_{G E M / C O}$ decreasing with burn stage progression (Table 5). Mean overall emission factors were higher for 
$E F_{G E M / C O 2}$, though both were within the range of uncertainty of $E F_{T H g / f u e l}$. $E F_{G E M / C O 2}$ significantly overpredicted GEM release during the flaming progression stage, though showed good agreement during the flaming stationary stage. $E F_{G E M / C O}$ showed good agreement with $E F_{T H g / f u e l}$ during the flaming progression and flaming stationary stages, though with uncertainties an order of magnitude higher than for $E F_{G E M / C O 2}$. Both emission factors significantly under-predicted GEM release against mass balance techniques during the smouldering stage.

\section{Discussion}

\subsection{Mercury in dry sclerophyll fuels and emission factors}

Observations of total mercury concentrations within eucalypt vegetation in the literature are rare but are in good agreement with those reported here (Table 22. Hellings et al. 35] observed concentrations of $78.5 \pm 2.1 \mu \mathrm{g} \mathrm{kg}^{-1}$ in Australian Eucalyptus leaves, similar to that seen in leaves from Site 1. Total mercury concentrations in eucalypt bark reported by these authors, at $50.1 \pm$ $2.5 \mu \mathrm{g} \mathrm{kg}^{-1}$, were slightly higher than those observed here. Packham et al. [58] similarly measured total mercury concentrations in biomass of 78, 80 and $83 \mu \mathrm{g} \mathrm{kg}^{-1}$ within three Walker fire regions [78] corresponding to native temperate broadleaf forest. Higher total mercury values within plant leaves have been observed elsewhere and are attributed to uptake of atmospheric mercury via stomatal and foliar exchange [23, 9]. Preferential storage of mercury within the leaves of eucalypts leads to emission factors across the entire fuel bed that are significantly lower than the maximum observed mercury concentrations. Clearly, the very low mercury content within the coarse fuels lead to an effective decrease in the mercury emission factor with increasing coarse fuel loading. The contribution to atmospheric emissions of coarse woody debris in Australian eucalypt forests is poorly known [77, due to the focus on fine fuels as the driver of fire propagation [42]. Field observations have further shown high variability in both fuel loading from coarse material and volatilisation of coarse material 
during biomass burning events [61]. Due to the low total mercury concentrations in coarse woody debris, the large disparity in burning efficiency of this material, and the large uncertainties in coarse fuel loading within Australian dry sclerophyll forests, we refrain from including coarse fuels in our estimate of mercury emission factors. As such, we conservatively offer an emission factor value of $28.7 \pm 8.1 \mu \mathrm{g} \mathrm{kg}^{-1}$ as an upper estimate of mercury emission from Australian dry sclerophyll litter fuels.

Volatilisation of mercury from soils is another significant emission contribution during biomass burning. THg concentrations in Site 2 soils (Table 2 ) were comparable to those reported by Hellings et al. [35, who observed concentrations of $30.1 \pm 1.5 \mu \mathrm{g} \mathrm{kg}^{-1}$ in soil with particle diameter above $212 \mu \mathrm{m}$ and $61.7 \pm 3.6 \mu \mathrm{g} \mathrm{kg}^{-1}$ below this diameter. Packham et al. [58] observed a soil total mercury concentration of $47 \mu \mathrm{g} \mathrm{kg}^{-1}$ at one Australian native temperate broadleaf sites and a concentration of $125 \mu \mathrm{g} \mathrm{kg}^{-1}$ at a second site, although stating that proximity to an old gold mine likely skewed this latter result. The similar differences in concentrations between upper $(0-2 \mathrm{~cm})$ and lower $(5-10$ $\mathrm{cm}$ ) soil depths at the burned and unburned sampling sites suggests that volatilisation of mercury from the soil was low during this particular fire. The general validity of this result is difficult to quantify without more extensive spatial sampling, however Biswas et al. [8] suggested that between 15 and $66 \%$ of soil mercury may be released during biomass burning events. Using the higher of the two soil concentrations from Site 2, this would equate to an estimated soil mercury emission factor between 4.4 and $32.5 \mu \mathrm{g} \mathrm{kg}^{-1}$.

In the absence of locally-derived emission factors, the work of Friedli et al. [27, 25] is commonly referred to in modelling of mercury release from biomass burning in Australia. These emission factors include a "global average" of $112 \mu \mathrm{g} \mathrm{kg}^{-1}$ [27] and diversified emission factors for tropical $\left(19 \mu \mathrm{g} \mathrm{kg}^{-1}\right)$, extratropical $\left(242 \mu \mathrm{g} \mathrm{kg}^{-1}\right)$ and non-forest $\left(41 \mu \mathrm{g} \mathrm{kg}^{-1}\right)$ regions [25]. For dry sclerophyll forests, we have shown through our own sampling and comparison with other values in the literature that mercury emission factors are considerably lower than both the global average and that for extratropical forests of 
$242 \mu \mathrm{g} \mathrm{kg}^{-1}$. Applying a mercury emission factor of $28.7 \mu \mathrm{g} \mathrm{kg}^{-1}$ would result in estimates of mercury release from eucalypt forest biomass burning between 74 and $88 \%$ lower than previously reported.

\subsection{GEM and PBM emission ratios}

In the emission time series (Fig. 3) it is apparent that the majority of GEM release occurs under flaming combustion, a stage characterised by the most efficient combustion (higher MCE) and the highest proportion of fuel carbon loss.

${ }_{440} \mathrm{As}_{\mathrm{CO}_{2}}$ emission represents the largest proportion of fuel carbon loss throughout all burn stages, a stronger linearity between $\triangle \mathrm{GEM}$ and $\Delta \mathrm{CO}_{2}$ is observed, relative to $\triangle \mathrm{GEM} / \triangle \mathrm{CO}$ (Fig. 4a,b). Applying $E R_{G E M / C O 2}$ values from all burn stages or during the flaming progression stage however significantly overestimates GEM release against mass balance techniques (Table 5). Values for $E R_{G E M / C O 2}$ in the literature are rare, with only one other study publishing a value of $1.19 \times 10^{-9}\left[10\right.$. All $E R_{G E M / C O 2}$ values observed here are significantly higher than this value, with the exception of smouldering-stage combustion, which was found to not be an accurate predictor of mercury release (Table 5). CGBAPS plume strike data similarly gave a mean $E R_{G E M / C O 2}$ value close to an order of magnitude higher than that reported by [10. The separation of burn stages was not able to be resolved in the CGBAPS field data, with neither $\Delta \mathrm{GEM} / \Delta \mathrm{CO}_{2}$ nor $\Delta \mathrm{GEM} / \Delta \mathrm{CO}$ values showing relationships with MCE similar to those seen in the experimental burns (Fig. 4 , f).

Brunke et al. [10] also reported an $E R_{G E M / C O}$ value of $2.10 \times 10^{-7}$, within the range of $0.79 \times 10^{-7}$ to $2.39 \times 10^{-7}$ from other reported values in the literature [27, 64, 81, 21]. Our own measurements of $E R_{G E M / C O}$ span a range greater than this within a single experimental burn ensemble $\left(0.08 \pm 0.01 \times 10^{-7}\right.$ for smouldering combustion to $2.51 \pm 0.03 \times 10^{-7}$ for flaming propagation). This result highlights the need for careful consideration of plume strike observations and we suggest reporting where possible both $E R_{G E M / C O 2}$ as well as $E R_{G E M / C O}$ values, along with MCE. Within our experimental burn data, $E R_{G E M / C O}$ values during the flaming stationary stage accurately predict GEM release against mass 
balance techniques (albeit with large uncertainty) and both $E R_{G E M / C O}$ values - and relationships between the $\Delta \mathrm{GEM} / \Delta \mathrm{CO}$ ratio and $\mathrm{MCE}$ - are similar to the CGBAPS field data. For this reason, we speculate that the $E R_{G E M / C O}$ obtained from CGBAPS plume strike data $\left(0.58 \times 10^{-7}\right)$ is a more appropriate value to adopt than the global average of Friedli et al. [25] $\left(1.54 \times 10^{-7}\right)$. Again, this is $62 \%$ lower than currently accepted values in the literature, highlighting that biomass burning emission of GEM in dry sclerophyll forests is currently overestimated.

With release of PBM below detection limits for many of the experimental burns, we are unable to provide an emission ratio for particulate mercury release. Obrist et al. [56] observed changes in the relative emission of gaseous and particulate mercury with combustion phase, highlighting increased PBM emis475 sion from smouldering-dominated fires in a laboratory-scale experiment. They explored emissions from fuels with initial moisture contents ranging between 9 and $95 \%$. For fuels with moisture content below $30 \%$ they saw very little release of PBM, at times below detection limits. As starting fuel moisture here was kept consistent and relatively low, the very small PBM releases observed are consistent with this result.

Fire intensities during wild burning events are strongly related to fuel moistures [29], and fuel moistures in this experiment were chosen such that the Byram fireline intensities of the experimental burns are similar to those observed during prescribed burning. Conditions during prescribed burns are chosen such that the resulting burn intensity is low and therefore controllable. Many wildfire burning events in Australia can also be considered low intensity, with an estimated $\sim 50 \%$ showing Byram fire line intensities around $300 \mathrm{~kW} \mathrm{~m}^{-1}[29$, within the range of intensities seen during heading experimental burns. Larger, more intense fires generally take place under drier conditions. For this reason we speculate that the very low release of PBM during dry sclerophyll forest biomass burning is broadly applicable; as such we would expect PBM to generally represent a very small proportion of mercury emission from wildfire burning in Australian dry sclerophyll forests. Estimating the moisture content of fuels is 
still an important step in resolving relative partitioning during mercury biomass

\subsection{Directions for future Australian research}

There has been a considerable range of biomass burning mercury emission estimates for the Australian continent produced in the literature. Using three biomass burning inventories, Simone et al. 65. provided estimates of 7, 30.0 and $30.2 \mathrm{Mg} \mathrm{Hg} \mathrm{a}{ }^{-1}$, based on the $E R_{G E M / C O}$ value of $1.54 \times 10^{-7}$ reported by Friedli et al. [25]. Estimates of total mercury release from the Australian continent using emission factors include those by Nelson et al. [55] (42 $\mathrm{Mg} \mathrm{Hg} \mathrm{a}^{-1}$ using an average emission factor of $112 \mu \mathrm{g} \mathrm{kg}^{-1}$ ) and Friedli et al. 25] (19 $\mathrm{Mg} \mathrm{Hg} \mathrm{a}^{-1}$ using diversified emission factors for tropical, extratropical and non-forest regions). We have shown here, through both experimental and field observation data, that these emission factors and emission ratios significantly overpredict mercury release for dry sclerophyll forests.

This significant downward adjustment is an important result for predicting mercury emissions from burning of dry sclerophyll forests. However according to AVHHR satellite data, biomass burning of temperate broadleaf forests accounted for only $0.7 \%$ of the total across Australia on an areal basis over the years 1997-2011 [47. Larger gains in constraining estimates of mercury release from biomass burning across the Australian continent can be made by focussing on tropical/subtropical grassland and savanna, and desert/xeric shrub ecoregions, which combined account for over $97 \%$ of burned area. In addition to the large relative burned areas, total mercury concentrations within vegetation and soils in these regions are currently subject to large uncertainty. Packham et al. [58] observed vegetation concentrations of 212 and $290 \mu \mathrm{g} \mathrm{kg}{ }^{-1}$ for tropical grassland and shrubland ecoregion samples, respectively, and soil concentra520 tions of $105 \mu \mathrm{g} \mathrm{kg}^{-1}$ for tropical grassland ecoregion samples. These results agree well with the $198 \mu \mathrm{g} \mathrm{kg}^{-1}$ mercury emission factor given by Friedli et al. 25] for tropical regions. Howard et al. [40] however observed vegetation and soil concentrations in a tropical grassland site of only $9 \mu \mathrm{g} \mathrm{kg}^{-1}$, stating that these 
samples were taken in an area that had undergone burning within the previous 12 months. Clearly further vegetation and soil sampling in these ecoregions can assist in constraining Australian biomass burning mercury emission estimates.

\section{Conclusions}

Mercury and greenhouse gas emissions from the burning of dry sclerophyll surface fuels were measured in the CSIRO Pyrotron combustion wind tunnel. This experimental setup provided a unique ability to observe changes in relative emissions due to fire progression throughout the burns. Heading and backing fires were considered both with and without the addition of coarse fuels. Due to the relatively low mercury concentrations in these fuels, increasing the coarse loading lead to an effective decrease in mercury concentration across the entire fuel bed. PBM represented less than $1 \%$ of emitted mercury, which we attributed to the consistent and relatively low fuel moistures used in this experiment. As this experiment was designed to simulate fire intensity conditions during prescribed burns (i.e. higher fuel moisture than during large wildfires), we hypothesise that wildfire burning events will likely emit similarly small percentages of PBM.

Volatilisation of mercury was found to occur predominantly during the early flaming combustion phase of the burns when flame temperatures are highest. Values of $E R_{G E M / C O 2}$ significantly over-predicted mercury release during the early stages of the burn, whilst $E R_{G E M / C O}$ values in the early stages agreed well with mercury release predicted from mass balance techniques. As the onset of smouldering combustion occurred after this early volatile period, mercury emissions at this stage were low, with both $E R_{G E M / C O 2}$ and $E R_{G E M / C O}$ significantly under-predicting mercury release. $E R_{G E M / C O}$ values observed during experimental burns spanned a range greater than those reported in the literature, however those obtained during the flaming stationary stage of the burns $\left(0.56 \pm 0.01 \times 10^{-7}\right)$ were deemed to give the most realistic representations of mercury release from the fuels. Comparison with plume strike data collected 
from CGBAPS $\left(0.58 \pm 0.01 \times 10^{-7}\right)$ confirmed this as the most appropriate value for estimating mercury release. These values are $\sim 62 \%$ lower than the global average used previously in Australian biomass burning mercury release modelling.

Fuel mercury concentrations at the two eucalypt sites agreed well with each other and with other values for eucalypt vegetation and soils reported in the literature. Based on our observations, we offer a conservative mercury emission factor of $28.7 \pm 8.1 \mu \mathrm{g} \mathrm{kg}^{-1}$ for surface fuels, noting that inclusion of coarse fuels in our calculations leads to a decrease in this estimate. Our estimated range of mercury emission factors for eucalypt soils is between 4.4 and $32.5 \mu \mathrm{g} \mathrm{kg}^{-1}$. Both of these values are again considerably lower than previous emission factors used in modelling emission of mercury from biomass burning in Australia. This is an important result for mercury emission modelling efforts however we note that, in terms of total area burned, eucalypt forests represent a relatively minor source of biomass burning emissions across the Australian continent. Future investigations into Australian mercury biomass burning release should be focused on the tropical grassland and desert shrub ecoregions, as these are the regions that are burned most extensively and frequently, thus potentially being regions of high atmospheric mercury turnover.

\section{Acknowledgements}

This work was supported by the Victorian Department of Environment, Land, Water and Planning and the Australian Bureau of Meteorology/CSIRO 575 Cape Grim Program. The authors thank Martin Cope of CSIRO Oceans and Atmosphere for leading the experimental burn project and Sam Cleland, Jeremy Ward, Nigel Somerville, Stuart Baly and Cindy Hood of the Bureau of Meteorology for their continued efforts in operating the Cape Grim Baseline Air Pollution Station. 


\section{Competing Interests}

The authors declare that they have no competing interests, financial or otherwise.

\section{References}

[1] Aalde, H., van Amstel, A., Gonzalez, P., Gytarsky, M., Krug, T., Kurz, W. A., Lasco, R. D., Martino, D. L., McConkey, B. G., Ogle, S., Paustian, K., Raison, J., Ravindranath, N. H., Schoene, D., Smith, P., Somogyi, Z. and Verchot, L. [2006], Generic methodologies applicable to multiple landuse categories, in H. S. Eggleston, L. Buendia, K. Miwa, T. Ngara and K. Tanabe, eds, '2006 IPCC Guidelines for National Greenhouse Gas Inventories', Institute for Global Environmental Strategies (IGES) for the Intergovernmental Panel on Climate Change (IPCC), Hayama, Japan, pp. 159.

[2] Abey, D. [2016], 'Call to put politics aside in fight for World Heritage wilderness in wake of fire threat', Mercury 31st Jan.

[3] Agnan, Y., Dantec, T. L., Moore, C. W., Edwards, G. C. and Obrist, D. [2016], 'New constraints on terrestrial surface-atmosphere fluxes of gaseous elemental mercury using a global database', Environmental Science and Technology 50(2), 507-524.

[4] Amos, H. M., Jacob, D. J., Streets, D. G. and Sunderland, E. M. [2013], 'Legacy impacts of all-time anthropogenic emissions on the global mercury cycle', Global Biogeochemical Cycles 27(2), 410-421.

[5] Andreae, M. and Merlet, P. [2001], 'Emission of trace gases and aerosols from biomass burning', Global Biogeochemical Cycles 15(4), 955-966.

[6] Australian Government Department of the Environment and

Energy (DEE) [2016], 'Australia's native vegetation frame-


work', http://www.environment.gov.au/land/publications/ australias-native-vegetation-framework. Accessed: 2017-06-01.

[7] Bailey, R. G. [1995], Description of the ecoregions of the United States, 2nd edn, Misc. Pub. No. 1391, Map scale 1:7,500,000. USDA Forest Service.

[8] Biswas, A., Blum, J. D., Klaue, B. and Keeler, G. J. [2007], 'Release of mercury from Rocky Mountain forest fires', Global Biogeochemical Cycles $\mathbf{2 1}(1), 13$.

[9] Blackwell, B. D. and Driscoll, C. T. [2015], 'Deposition of mercury in forests along a montane elevation gradient', Environmental Science and Technology 49(9), 5363-5370.

[10] Brunke, E.-G., Labuschagne, C. and Slemr, F. [2001], 'Gaseous mercury emissions from a fire in the Cape Peninsula, South Africa, during January 2000', Geophysical Research Letters 28(8), 1483-1486.

[11] Byram, G. M. [1959], Combustion of forest fuels, in K. P. Davis, ed., 'Forest Fire: Control and Use', McGraw, New York, NY, United States, pp. 61-89.

[12] Chatto, K. and Tolhurst, K. G. [1997], Development and testing of the Wiltronics TH fine fuel moisture meter, Technical report, Research Report 46, Department of Natural Resources and Environment, Fire Management Branch, Victoria, Australia.

[13] Cheney, N. P., Gould, J. S. and Catchpole, W. R. [1993], 'The influence of fuel, weather and fire shape variables on fire-spread in grasslands', International Journal of Wildland Fire 3(1), 31-44.

[14] Cobbett, F. D. and Van Heyst, B. J. [2007], 'Measurements of GEM fluxes and atmospheric mercury concentrations (GEM, RGM and $\mathrm{Hg}^{\mathrm{p}}$ ) from an agricultural field amended with biosolids in Southern Ont., Canada (October 2004-November 2004)', Atmospheric Environment 41(11), 2270-2282. 
[15] Cope, M. E., Hess, G. D., Lee, S., Tory, K., Azzi, M., Carras, J., Lilley, W., Manins, P. C., Nelson, P., Ng, L., Puria, K., Wong, N., Walsh, S. and Young, M. [2009], 'The Australian air quality forecasting system. Part I: Project description and early outcomes', Journal of Applied Meteorology 43(5), 649-662.

[16] Desservettaz, M., Paton-Walsh, C., Griffith, D. W., Kettlewell, G., Keywood, M. D., van der Schoot, M. V., Ward, J., Mallet, M. D., Milic, A., Miljevic, B., Ristovski, Z. D., Howard, D., Edwards, G. C. and Atkinson, B. [2017], 'Emission factors of trace gases and particles from tropical savanna fires in Australia', Journal of Geophysical Research: Atmospheres 122(11), 6059-6074.

[17] Draxler, R. R. [1999], HYSPLIT4 user's guide, Technical Report ERL ARL230, NOAA Air Resources Laboratory, Silver Spring, MD, United States.

[18] Draxler, R. R. and Hess, G. [1998a], Description of the HYSPLIT_4 modeling system, Technical Report ERL ARL-224, NOAA Air Resources Laboratory, Silver Spring, MD, United States.

[19] Draxler, R. R. and Hess, G. [1998b], 'An overview of the HYSPLIT 4 modelling system for trajectories', Australian Meteorological Magazine 47, 295308.

[20] Driscoll, C. T., Mason, R. P., Chan, H. M., Jacob, D. J. and Pirrone, N. [2013], 'Mercury as a global pollutant: Sources, pathways, and effects', Envrionmental Science and Technology 47(10), 4967-4983.

[21] Ebinghaus, R., Slemr, F., Brenninkmeijer, C. A. M., van Velthoven, P., Zahn, A., Hermann, M., O'Sullivan, D. A. and Oram, D. E. [2007], 'Emissions of gaseous mercury from biomass burning in South America in 2005 observed during CARIBIC flights', Geophysical Research Letters 34(8), 5 pp. 
[22] Ericksen, J. A. and Gustin, M. S. [2004], 'Foliar exchange of mercury as a function of soil and air mercury concentrations', Science of The Total Environment 324(1-3), 271-279.

[23] Ericksen, J. A., Gustin, M. S., Schorran, D. E., Johnson, D. W., Lindberg, S. E. and Coleman, J. S. [2003], 'Accumulation of atmospheric mercury in forest foliage', Atmospheric Environment 37(12), 1613-1622.

[24] Fitzgerald, W. F., Engstrom, D. R., Mason, R. P. and Nater, E. A. [1998], 'The case for atmospheric mercury contamination in remote areas', Environmetnal Science and Technology 32(1), 1-7.

[25] Friedli, H. R., Arellano, A. F., Cinnirella, S. and Pirrone, N. [2009], 'Initial estimates of mercury emissions to the atmosphere from global biomass burning', Envrionmental Science and Technology 43(10), 3507-3513.

[26] Friedli, H. R., Radke, L. F. and Lu, J. Y. [2001], 'Mercury in smoke from biomass fires', Geophysical Research Letters 28(17), 323-3226.

[27] Friedli, H. R., Radke, L. F., Lu, J. Y., Banic, C. M., Leaitch, W. R. and MacPherson, J. I. [2003], 'Mercury emissions from burning of biomass from temperate North American forests: laboratory and airborne measurements', Atmospheric Environment 37(2), 253-267.

[28] Gill, A. M. [1981], Adaptive responses of Australian vascular plant species to fires, in A. M. Gill, R. H. Groves and I. R. Noble, eds, 'Fire and the Australian biota', Australian Academy of Science, Canberra, Australia, pp. 101-27.

[29] Gill, A. M. and Catling, P. C. [2002], Fire regimes and biodiversity of forested landscapes of southern australia, in R. A. Bradstock, J. E. Williams and A. M. Gill, eds, 'Flammable Australia: the fire regimes and biodiversity of a continent', Cambridge University Press, Melbourne, Australia, pp. 353-363. 
[30] Gramenz, E. [2016], 'Tasmanian bushfires: Firefighters gear up for at least four more weeks battling blazes', Australian Broadcasting Corporation $(A B C)$ News .

[31] Griffith, D. W. T. [1996], 'Synthetic calibration and quantitative analysis of gas-phase FT-IR spectra', Applied Spectroscopy 50(1), 59-70.

[32] Griffith, D. W. T., Deutscher, N. M., Caldow, C., Kettlewell, G., Riggenbach, M. and Hammer, S. [2012], 'A Fourier transform infrared trace gas and isotope analyser for atmospheric applications', Atmospheric Measurement Techniques 5(10), 2481.

[33] Hao, W. M. and Ward, D. E. [1993], 'Methane production from global biomass burning', Journal of Geophysical Research: Atmospheres 98(D11), 20657-20661.

[34] Hartman, J. S., Weisberg, P. J., Pillai, R., Ericksen, J. A., Kuiken, T., Lindberg, S. E., Zhang, H., Rytuba, J. J. and Gustin, M. S. [2009], 'Application of a rule-based model to estimate mercury exchange for three background biomes in the continental United States', Environmental Science and Technology 43(13), 4989-4994.

[35] Hellings, J., Adeloju, S. B. and Verheyen, T. V. [2013], 'Rapid determination of ultra-trace concentrations of mercury in plants and soils by cold vapour inductively coupled plasma-optical emission spectrometry', Microchemical Journal 111, 62-66.

[36] Hintelmann, H., Harris, R., Heyes, A., Hurley, J. P., Kelly, C. A., Krabbenhoft, D. P., Lindberg, S., Rudd, J. W., Scott, K. J. and St.Louis, V. L. [2002], 'Reactivity and mobility of new and old mercury deposition in a boreal forest ecosystem during the first year of the METAALICUS study', Environmental Science and Technology 36(23), 5034-5040.

[37] Holmes, C., Jacob, D., Corbitt, E., Mao, J., Yang, X., Talbot, R. and Slemr, 
F. [2010], 'Global atmospheric model for mercury including oxidation by bromine atoms', Atmospheric Chemistry and Physics 10, 12037-12057.

[38] Horowitz, H. M., Jacob, D. J., Zhang, Y., Dibble, T. S., Slemr, F., Amos, H. M., Schmidt, J. A., Corbitt, E. S., Marais, E. A. and Sunderland, E. M. [2017], 'A new mechanism for atmospheric mercury redox chemistry: implications for the global mercury budget', Atmospheric Chemistry and Physics 17, 6353-6371.

[39] Howard, D. and Edwards, G. C. [2018], 'Mercury fluxes over an Australian alpine grassland and observation of nocturnal atmospheric mercury depletion events', Atmospheric Chemistry and Physics 18(1), 129-142.

[40] Howard, D., Nelson, P. F., Edwards, G. C., Morrison, A. L., Fisher, J. A., Ward, J., Harnwell, J., van der Schoot, M., Atkinson, B., Chambers, S. D., Griffiths, A. D., Werczynski, S. and Williams, A. G. [2017], 'Atmospheric mercury in the southern hemisphere tropics: seasonal and diurnal variations and influence of inter-hemispheric transport', Atmospheric Chemistry and Physics 17(18), 11623-11636.

[41] Johnson, D. W. and Lindberg, S. E. [1995], 'The biogeochemical cycling of $\mathrm{Hg}$ in forests: Alternative methods for quantifying total deposition and soil emission', Water, Air, and Soil Pollution 80(1-4), 1069-1077.

[42] Keeley, J. E. [2009], 'Fire intensity, fire severity and burn severity: a brief review and suggested usage', Journal of the International Association of Wildland Fire 18(1), 116-126.

[43] Kessler, R. [2013], 'The Minamata Convention on Mercury: a first step toward protecting future generations', Environmental Health Perspectives 121(10), 304-309.

[44] Krabbenhoft, D. P. and Sunderland, E. M. [2013], 'Global change and mercury', Science 341, 1457-1458. 
[52] Meyer, C. P., Cook, G. D., Reisen, F., Smith, T. E. L., Tattaris, M., Russell-Smith, J., Maier, S. W., Yates, C. P. and Wooster, M. J. [2012], 
'Direct measurements of the seasonality of emission factors from savanna fires in northern Australia', Journal of Geophysical Research: Atmospheres 117(D20), $14 \mathrm{pp}$.

[53] Montreal Process Implementation Group for Australia and National Forest Inventory Steering Committee [2013], Australia's state of the forests report 2013, Technical Report CC BY 3.0, Australian Bureau of Agricultural and Resources Economics and Sciences (ABARES), Canberra, Australia.

[54] Nelson, P. F., Morrison, A. L., Malfroy, H. J., Cope, M., Lee, S., Hibberd, M. L., Meyer, C. and McGregor, J. [2012], 'Atmospheric mercury emissions in Australia from anthropogenic, natural and recycled sources', Atmospheric Environment 62, 291-302.

[55] Nelson, P. F., Nguyen, H., Morrison, A. L., Malfroy, H., Cope, M. E., Hibberd, M. F., Lee, S., McGregor, J. L. and Meyer, M. [2009], Mercury sources, transportation and fate in Australia, Report, Department of Environment, Water, Heritage \& the Arts.

[56] Obrist, D., Moosmüller, H., Schürmann, R., Antony Chen, L.-W. and Kreidenweis, S. M. [2007], 'Particulate-phase and gaseous elemental mercury emissions during biomass combustion: Controlling factors and correlation with particulate matter emissions', Environmental Science and Technology 42(3), 721-727.

[57] Olson, D. M. and Dinerstein, E. [2002], The global 200: Priority ecoregions for global conservation, Technical Report Annals of the Missouri Botanical Garden 89:125-126. -The Nature Conservancy, USDA Forest Service and U.S. Geological Survey.

[58] Packham, D., Tapper, N., Griepsma, D., Friedli, H., Hellings, J. and Harris, S. [2009], 'Release of mercury in the Australian environment by burning: A preliminary investigation of biomatter and soils', Air Quality and Climate Change 43(1), 24-27. 
[59] Paton-Walsh, C., Smith, T. E. L., Young, E. L., Griffith, D. W. T. and Guérette, E.-A. [2014], 'New emission factors for Australian vegetation fires measured using open-path Fourier transform infrared spectroscopy - Part 1: Methods and Australian temperate forest fires', Atmospheric Chemistry and Physics 14(20), 11313-11333.

[60] Pirrone, N., Hedgecock, I., Cinnirella, S. and Sprovieri, F. [2010], Overview of major processes and mechanisms affecting the mercury cycle on different spatial and temporal scales, in 'EPJ Web of Conferences', Vol. 9, EDP Sciences, pp. 3-33.

[61] Possell, M., Jenkins, M., Bell, T. L. and Adams, M. A. [2015], 'Emissions from prescribed fires in temperate forest in south-east Australia: implications for carbon accounting', Biogeosciences 12(1), 257-268.

[62] Rea, A. W., Lindberg, S. E. and Keeler, G. J. [2001], 'Dry deposition and foliar leaching of mercury and selected trace elements in deciduous forest throughfall', Atmospheric Environment 35(20), 3453-3462.

[63] Selin, N. E. [2009], 'Global biogeochemical cycling of mercury: A review', Annual Review of Environment and Resources 34(43-63).

[64] Sigler, J. M., Lee, X. and Munger, W. [2003], 'Emission and long-range transport of gaseous mercury from a large-scale Canadian boreal forest fire', Environmental Science and Technology 37(19), 4343-4347.

[65] Simone, F. D., Cinnirella, S., Gencarelli, C. N., Yang, X., Hedgecock, I. M. and Pirrone, N. [2015], 'Model study of global mercury deposition from biomass burning', Environmental Science and Technology 49(11), 67126721.

${ }_{820}$ [66] Simone, F. D., Gencarelli, C. N., Hedgecock, I. M. and Pirrone, N. [2016], 'A modeling comparison of mercury deposition from current anthropogenic mercury emission inventories', Environmental Science and Technology 50(10), 5154-5162. 
[67] Slemr, F., Angot, H., Dommergue, A., Magand, O., Barret, M., Weigelt, A., Ebinghaus, R., Brunke, E.-G., Pfaffhuber, K., Edwards, G., Howard, D., Powell, J., Keywood, M. and Wang, F. [2015], 'Comparison of mercury concentrations measured at several sites in the Southern Hemisphere', Atmospheric Chemistry and Physics 15, 3125-3133.

[68] Smith-Downey, N. V., Sunderland, E. M. and Jacob, D. J. [2010], 'Anthropogenic impacts on global storage and emissions of mercury from terrestrial soils: Insights from a new global model', Journal of Geophysical Research: Biogeosciences 115(G3), 11 pp.

[69] Stamenkovic, J. and Gustin, M. S. [2009], 'Nonstomatal versus stomatal uptake of atmospheric mercury', Environmental Science and Technology 43(5), 1367-1372.

[70] Stein, A., Draxler, R., Rolph, G., Stunder, B., Cohen, M. and and, F. N. [2015], 'NOAAs HYSPLIT atmospheric transport and dispersion modeling system', Bulletin of the American Meteorological Society 96, 2059-2077.

[71] Streets, D. G., Devane, M. K., Lu, Z., Bond, T. C., Sunderland, E. M. and Jacob, D. J. [2011], 'All-time releases of mercury to the atmosphere from human activities', Environmental Scince and Technology 45(24), 1048510491.

[72] Streets, D. G., Horowitz, H. M., Jacob, D. J., Lu, Z., Levin, L., Ter Schure, A. F. H. and Sunderland, E. M. [2017], 'Total mercury released to the environment by human activities', Environmental Science and Technology 51(11), 5696-5977.

[73] Sullivan, A. L., Knight, I. K., Hurley, R. J. and Webber, C. [2013], 'A contractionless, low-turbulence wind tunnel for the study of free-burning fires', Experimental Thermal and Fluid Science 44, 264-274.

850

[74] Sullivan, A., Surawski, N., Crawford, D., Hurley, R., Volkova, L., Weston, C. and C.P.Meyer [2018], 'Effect of woody debris on the rate of spread of 
surface fires in forest fuels in a combustion wind tunnel', Forest Ecology and Management 424, 236-245.

[75] Surawski, N. C., Sullivan, A. L., Meyer, C. P., Roxburgh, S. H. and Polglase, P. J. [2015], 'Greenhouse gas emissions from laboratory-scale fires in wildland fuels depend on fire spread mode and phase of combustion', Atmospheric Chemistry and Physics 15(9), 5259-5273.

[76] Tolhurst, K. G. and Cheney, N. P. [1999], 'Synopsis of the knowledge used in prescribed burning in victoria.'.

[77] Volkova, L. and Weston, C. [2013], 'Redistribution and emission of forest carbon by planned burning in Eucalyptus obliqua (l. hérit.) forest of southeastern Australia', Forest Ecology and Management 304(15), 383-390.

[78] Walker, J. [1981], Fuel dynamics in Australian vegetation, in A. M. Gill, R. H. Groves and I. R. Noble, eds, 'Fire and the Australian biota', Australian Academy of Science, Canberra, Australia, pp. 101-27.

[79] Ward, D. E. and Radke, L. F. [1993], Emissions measurements from vegetation fires: A comparative evaluation of methods and results, in P. J. Crutzen and J. G. Goldammer, eds, 'Fire in the Environment: The Ecological, Atmospheric and Climatic Importance of Vegetation Fires. Report of the Dahlem Workshop, Berlin, 15-20 March, 1992', Atmospheric Chemistry Department, Max Planck Institute for Chemistry, Mainz, Germany, pp. $53-76$.

[80] Webster, J. P., Kane, T. J., Obrist, D., Ryan, J. N. and Aiken, G. R. [2016], 'Estimating mercury emissions resulting from wildfire in forests of the Western United States', Science of The Total Environment 568, 578586.

[81] Weiss-Penzias, P., Jaffe, D., Swartzendruber, P., Hafner, W., Chand, D. and Prestbo, E. [2007], 'Quantifying Asian and biomass burning sources of 
mercury using the $\mathrm{Hg} / \mathrm{CO}$ ratio in pollution plumes observed at the Mount Bachelor observatory', Atmospheric Environment 41(21), 4366-4379.

[82] Wright, L. P., Zhang, L. and Marsik, F. J. [2016], 'Overview of mercury dry deposition, litterfall, and throughfall studies', Atmospheric Chemistry and Physics 16, 13399-13416.

[83] Yokelson, R. J., Griffith, D. W. T. and Ward, D. E. [1996], 'Open-path fourier transform infrared studies of large-scale laboratory biomass fires', Journal of Geophysical Research 101(D15), 21067-21080. 
Table 1: Overview of burned area derived from AVHHR 1997-2011 data [7] and mean total mercury concentrations 58 reproduced for vegetation and soils, categorised by Australian ecoregions [57. Parentheses denote number of sample locations. ${ }^{*}$ Value of $125 \mu \mathrm{g} \mathrm{kg}{ }^{-1}$ removed, due to possible geogenic source contamination. ${ }^{\dagger}$ Values obtained from Howard et al. [40]. ${ }^{\ddagger}$ Values obtained from Howard and Edwards [39]

\begin{tabular}{lcccc}
\hline & $\begin{array}{c}\text { Total Area } \\
\text { Gha }\end{array}$ & $\begin{array}{c}\text { Area Burned } \\
\text { Gha a }\end{array}$ & $\begin{array}{c}\text { Vegetation }[\mathrm{THg}] \\
\mu \mathrm{g} \mathrm{kg}^{-1}\end{array}$ & $\begin{array}{c}\text { Soil }[\mathrm{THg}] \\
\mathrm{g} \mathrm{kg}^{-1}\end{array}$ \\
\hline $\begin{array}{c}\text { Tropical and Subtropical } \\
\text { Moist Broadleaf Forests }\end{array}$ & 2.77 & 0.03 & - & - \\
$\begin{array}{c}\text { Temperate Broadleaf } \\
\text { and Mixed Forests }\end{array}$ & 53.48 & 0.28 & $80(3)$ & $47^{*}(1)$ \\
$\begin{array}{c}\text { Tropical and Subtropical } \\
\text { Grasslands and Savannas }\end{array}$ & 188.41 & 27.37 & $212(1)$ & $105(1)$ \\
$\begin{array}{c}\text { Temperate Grasslands, } \\
\text { Savannahs and Shrublands }\end{array}$ & 48.96 & 0.06 & $52(1)$ & $145(1)$ \\
$\begin{array}{c}\text { Montane Grasslands } \\
\text { and Shrublands }\end{array}$ & 0.99 & 0.05 & $18^{\ddagger}(1)$ & $48^{\ddagger}(1)$ \\
Meditteranean Forests, & 74.08 & 0.43 & $213(2)$ & $90(1)$ \\
$\quad$ Woodlands and Scrub & & & & \\
$\begin{array}{c}\text { Deserts and } \\
\text { Xeric Schrubs }\end{array}$ & 321.69 & 12.74 & $290(1)$ & - \\
\hline
\end{tabular}


Table 2: Total mercury (THg) concentrations in different fuel types. Values are means \pm one standard deviation.

\begin{tabular}{lccc}
\hline & $\begin{array}{c}\text { Site 1 } \\
\mu \mathrm{g} \mathrm{kg}^{-1}\end{array}$ & $\begin{array}{c}\text { Site 2 (unburned) } \\
\mu \mathrm{g} \mathrm{kg}^{-1}\end{array}$ & $\begin{array}{c}\text { Site 2 (burned) } \\
\mu \mathrm{g} \mathrm{kg}^{-1}\end{array}$ \\
\hline Leaves & $72.9 \pm 10.9$ & $47.8 \pm 3.5$ & - \\
Bark & $25.0 \pm 11.1$ & $24.5 \pm 4.0$ & - \\
Twigs & $10.1 \pm 5.4$ & $11.2 \pm 4.1$ & - \\
Coarse $(6-25 \mathrm{~mm})$ & $4.3 \pm 3.8$ & - & - \\
Coarse $(25-50 \mathrm{~mm})$ & $6.1 \pm 8.1$ & - & - \\
Fine fuel residue & $1.6 \pm 1.6$ & - & - \\
Coarse fuel residue & $0.3 \pm 0.2$ & - & - \\
Soil $(0-2 \mathrm{~cm})$ & - & $29.4 \pm 17.7$ & $49.3 \pm 29.0$ \\
Soil $(5-10 \mathrm{~cm})$ & - & $25.3 \pm 11.8$ & $45.4 \pm 4.8$ \\
\hline
\end{tabular}

Table 3: Overview of fire behaviour parameters. Median with range in parentheses.

\begin{tabular}{|c|c|c|c|c|c|c|}
\hline & Fuel MC & $\min : \mathrm{sec}$ & $\begin{array}{l}\text { Flaming } \\
\text { duration } \\
\text { min:sec }\end{array}$ & $\begin{array}{c}\text { Max. point } \\
\text { temperature } \\
{ }^{\circ} \mathrm{C}\end{array}$ & $\begin{array}{l}\text { Rate of } \\
\text { spread } \\
\mathrm{m} \mathrm{h}^{-1}\end{array}$ & $\begin{array}{l}\text { Byram } \\
\text { intensity } \\
\mathrm{kW} \mathrm{m}^{-1}\end{array}$ \\
\hline Heading & $\begin{array}{c}11.5 \\
(10.0-12.7)\end{array}$ & $\begin{array}{c}4: 55 \\
(2: 19-6: 55)\end{array}$ & $\begin{array}{c}9: 06 \\
(6: 20-11: 20)\end{array}$ & $\begin{array}{c}726 \\
(107-958)\end{array}$ & $\begin{array}{c}47.7 \\
(36.7-112.6)\end{array}$ & $\begin{array}{c}211.5 \\
(115.7-478.4)\end{array}$ \\
\hline Backing & $\begin{array}{c}11.9 \\
(10.2-12.7)\end{array}$ & $\begin{array}{c}22: 41 \\
(19: 46-26: 54)\end{array}$ & $\begin{array}{c}28: 37 \\
(27: 44-29: 30)\end{array}$ & $\begin{array}{c}621 \\
(127-886)\end{array}$ & $\begin{array}{c}5.0 \\
(4.6-6.2)\end{array}$ & $\begin{array}{c}20.1 \\
(13.1-25.6)\end{array}$ \\
\hline
\end{tabular}


Table 4: Mercury emission ratios for all fire stages. Calculated as the least squares slope of GEM/ $y$ with standard error.

\begin{tabular}{|c|c|c|c|c|c|}
\hline & All Data & $\begin{array}{c}\text { Flaming } \\
\text { Progression }\end{array}$ & $\begin{array}{c}\text { Flaming } \\
\text { Stationary }\end{array}$ & Smouldering & Cape Grim \\
\hline $\operatorname{GEM}_{\mathrm{CO} 2}\left(\times 10^{-9}\right)$ & $5.95 \pm 0.02$ & $6.55 \pm 0.05$ & $4.70 \pm 0.07$ & $1.46 \pm 0.10$ & $9.77 \pm 0.08$ \\
\hline $\operatorname{GEM}_{\mathrm{CO}}\left(\times 10^{-7}\right)$ & $0.82 \pm 0.01$ & $2.51 \pm 0.03$ & $0.56 \pm 0.01$ & $0.08 \pm 0.01$ & $0.58 \pm 0.01$ \\
\hline MCE range & $0.80-1.00$ & $0.96-1.00$ & $0.88-0.96$ & $0.80-0.88$ & $0.79-0.97$ \\
\hline
\end{tabular}

Table 5: Mercury emission factors for all fire stages. Emission factor calculated from mass balance technique $\left(\mathrm{EF}_{\mathrm{THg} / \text { fuel }}\right)$ included for reference.

\begin{tabular}{lccccc}
\hline & $\mathrm{EF}_{\mathrm{THg} / \text { fuel }}$ & All Data & $\begin{array}{c}\text { Flaming } \\
\text { Progression }\end{array}$ & $\begin{array}{c}\text { Flaming } \\
\text { Stationary }\end{array}$ & Smouldering \\
& & & $32.8 \pm 0.8$ & $29.0 \pm 1.3$ & $7.8 \pm 1.0$ \\
$\mathrm{GEM}_{\mathrm{CO} 2} / \mu \mathrm{g} \mathrm{kg}^{-1}$ & $28.7 \pm 8.1$ & $37.4 \pm 0.7$ & $42.8 \pm 10.7$ & $8.7 \pm 10.5$ \\
\hline $\mathrm{GEM}_{\mathrm{CO}} / \mu \mathrm{g} \mathrm{kg}^{-1}$ & $28.7 \pm 8.1$ & $31.5 \pm 7.0$ & $28.8 \pm 14.7$ & $25.7 \pm 10.1$ & 8 \\
\hline
\end{tabular}




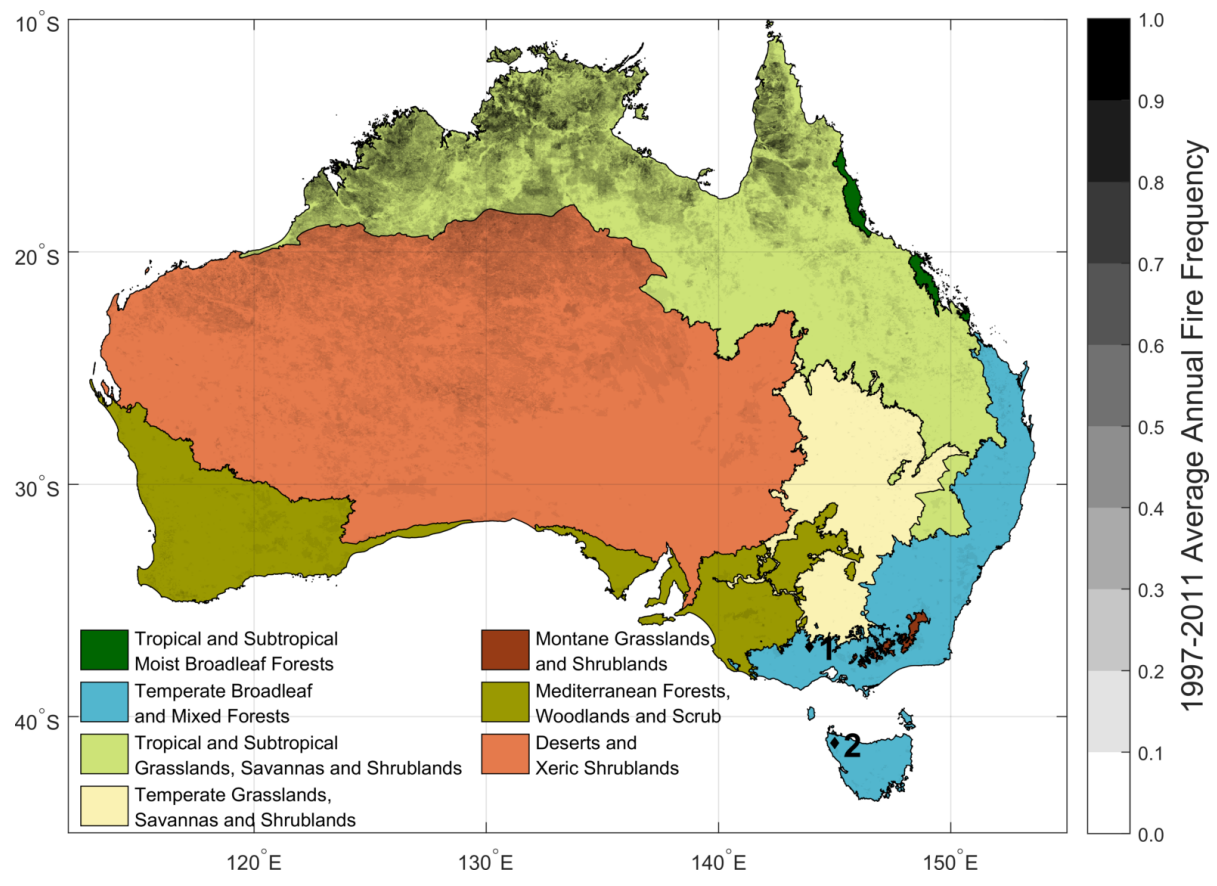

Figure 1: Map of Australian biomes as defined by Olson and Dinerstein [57, along with average annual fire frequency as determined by Maier [47. Based on raster data at $1 \mathrm{~km}^{2}$ resolution. Due to the sampling algorithm, generally only fires of size $4 \mathrm{~km}^{2}$ or larger are counted. Numbers 1 and 2 show locations of fuel sampling sites. 


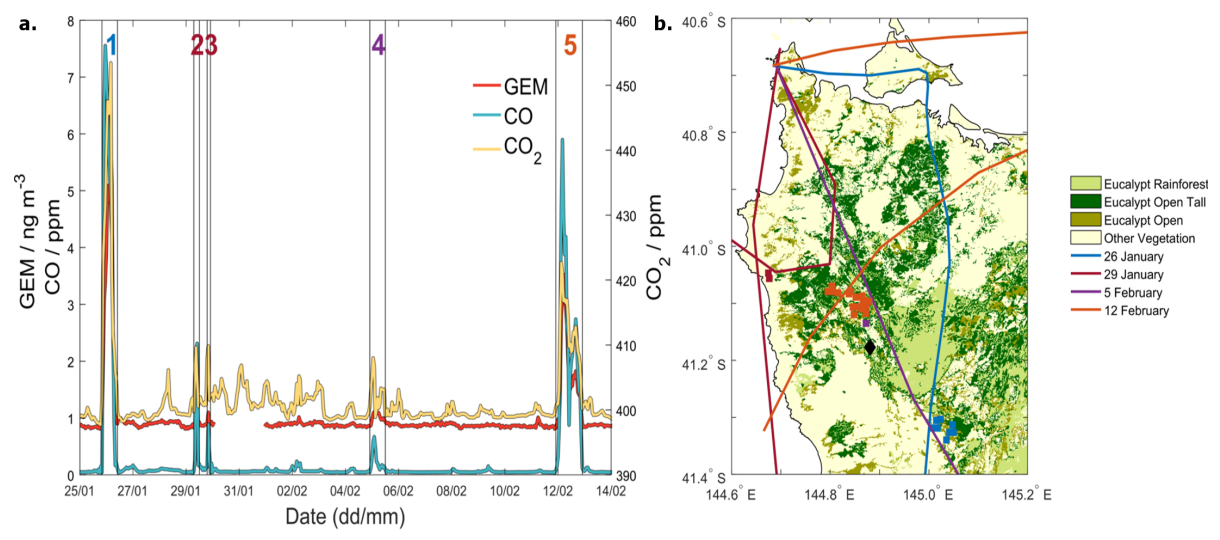

Figure 2: a. time series of GEM, $\mathrm{CO}_{2}$ and $\mathrm{CO}$ as observed at CGBAPS during 25th January - 14th February, 2016. Vertical lines denote the start and end times of identified plume strike events. b. HYSPLIT back trajectories corresponding to identified plume strike events, along with MODIS hot spot data for corresponding days. 

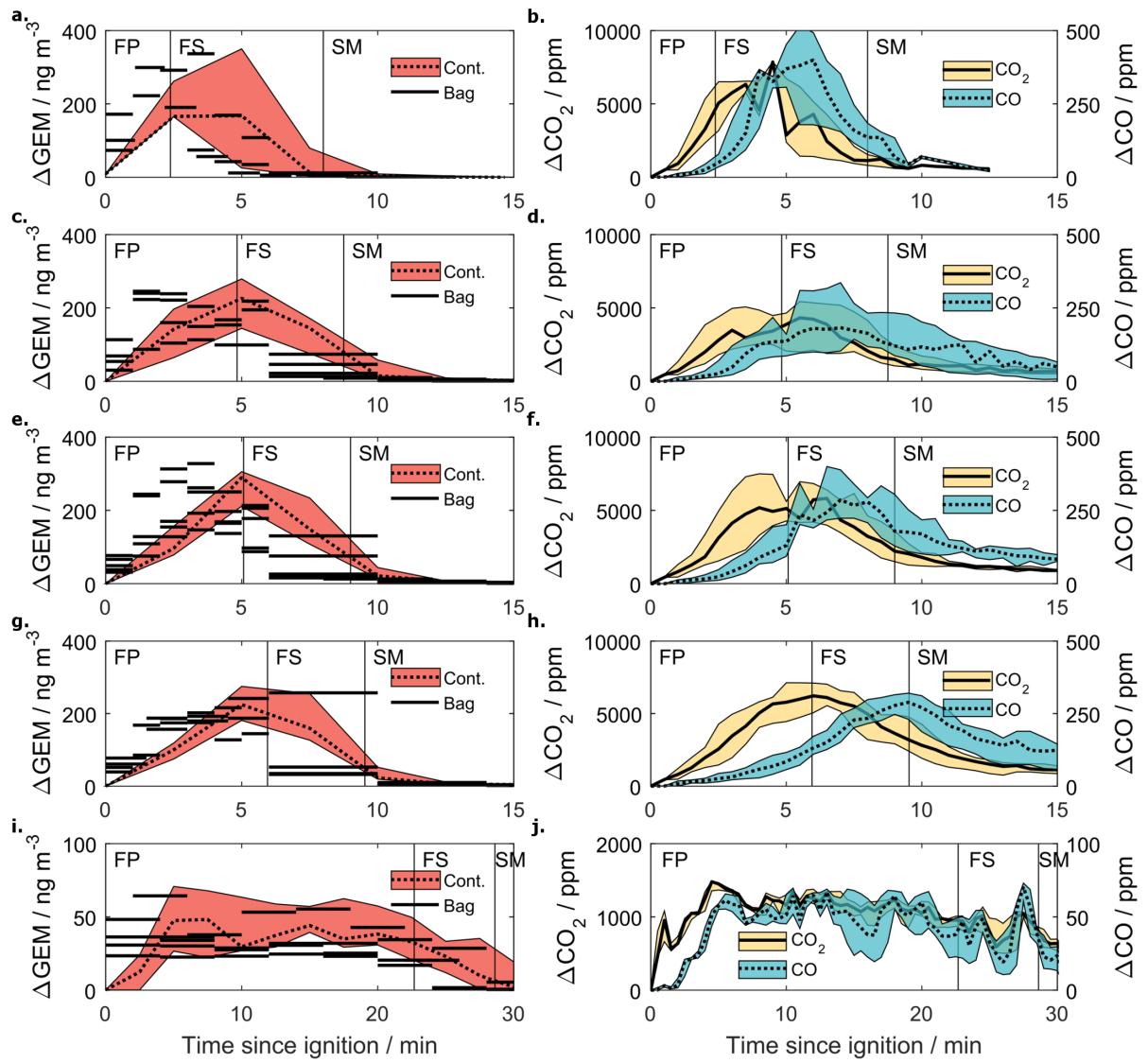

Figure 3: Left: time series of GEM enhancements for a. Load 1, c. Load 2, e. Load 3, g. Load 4 and i. backing fires. Right: $\mathrm{CO}_{2}$ (yellow) and $\mathrm{CO}$ (blue) enhancements for the same fires. Black lines denote median values, shading denotes range of values. Vertical lines show median times of EOFS and Fines Out. 

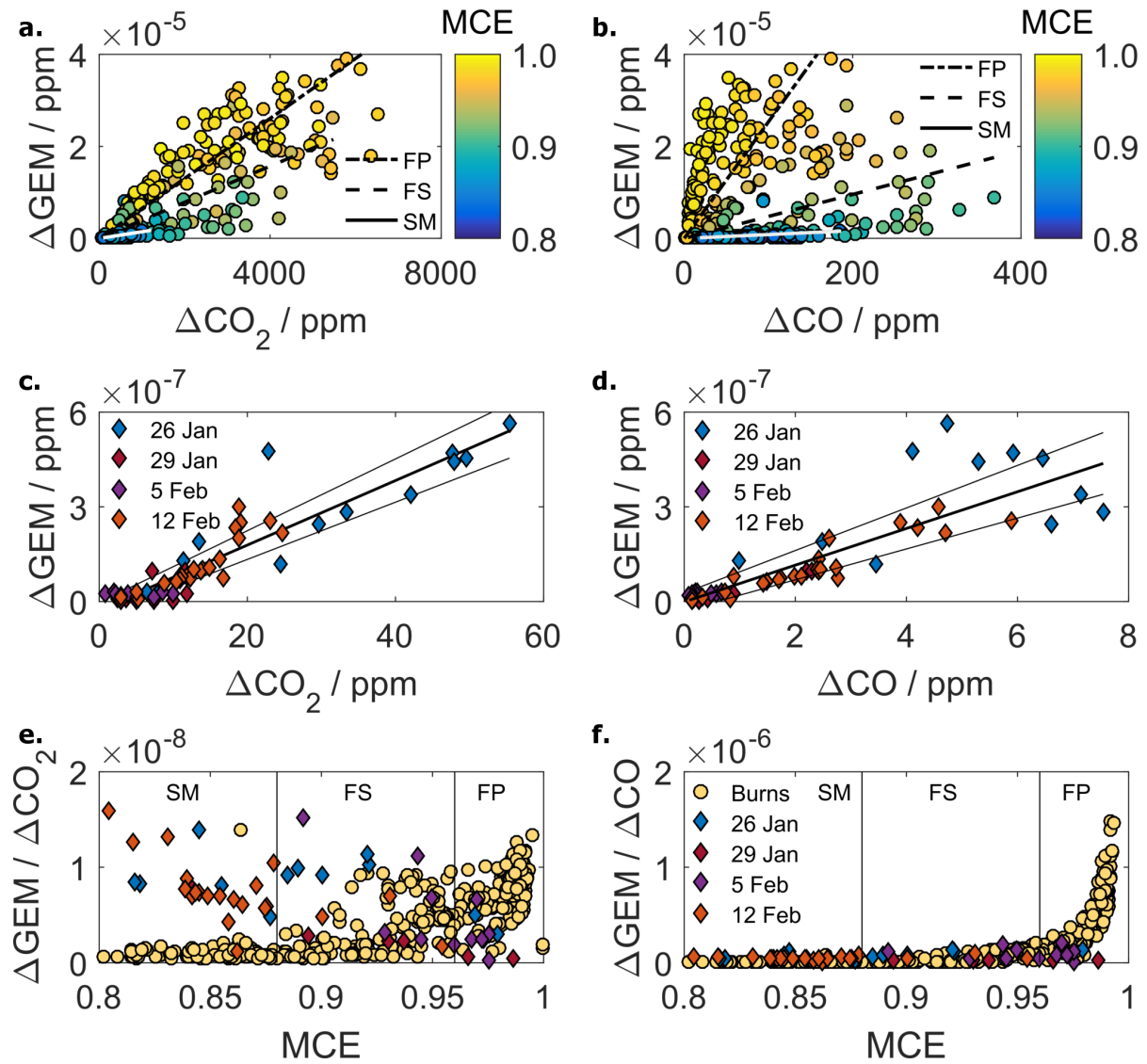

Figure 4: Above: GEM enhancements against a. $\mathrm{CO}_{2}$ and b. $\mathrm{CO}$ enhancements. Lines show least-squares regressions for FP (dotted), FS (dashed) and SM (solid) stages. Middle: GEM enhancements against c. $\mathrm{CO}_{2}$ and d. $\mathrm{CO}$ enhancements for plume strike events observed at CGBAPS. Lines show linear least-square regressions \pm standard error. Below: e. $\Delta \mathrm{GEM} / \Delta \mathrm{CO}_{2}$ and f. $\Delta \mathrm{GEM} / \Delta \mathrm{CO}$ ratios for each observation against modified combustion efficiency for experimental burn (circles) and CGBAPS plume strike (diamonds) data. Here FP, FS and SM categories are defined according to MCE ranges and refer to experimental burn data only. 